\title{
5 軸制御加工における工具干渉検出と回避法に関する研究*
}

\author{
小西和 正** 福田好 朗*** 岩田一 明 ${ }^{\dagger}$
}

Study on a Method of Collision Check and Collision Avoidance for 5-Axis Control Machining

Kazumasa Konishi, Yoshirou Funuda and Kazuaki Iwata

This paper deals with a method of collision check and collision avoidance on the tool path generation for 5 -axis control machining. The proposed method is able to reliably check the collision between tooling system and objects which surround the tooling system. The method is to determine whether edges of polygon patches on the surface of the objects are intersecting to the tooling system or not. The avoidance value is quickly calculated in order to get tool posture without collision, when the collision is found. The CAM system has been developed in this study, and it has been applied to machining for a marine propeller. The validity of the proposed method is experimentally confirmed by the machined propeller and its measured result.

Key words: collision check, collision avoidance, 5-axis control machining, CAM, avoidance value, marine propeller

\section{1. 緒}

同時 5 軸制御加工においては，工作物に対して任意の工具姿 勢を与えることができることから，オーバハング部を有する自 由曲面等の複雑な形状の加工，ルールド曲面に対する工具側面 による線切削, 段取換えを省いた高能率な加工等が可能であ る. しかしながら, 工具軸の傾け方によっては工具系（工具, 工具ホルダ, スピンドル, 主軸) とテーブル系（工作物, ジ グ, テーブル) 間に干渉が生じる. このため, 自由曲面等の複 雑な形状の工作物の加工に対して，工具系とテーブル系間に生 じる干渉を高速にかつ確実に検出技よび回避することのでさる 同時 5 軸制御加工用 CAM ソフトゥェアの開発が望まれてい る.

同時 5 軸制御加工における工具干渉検出および干渉回避につ いては，既にいくつかの論文が発表されている．代表的なもの として，工具に多数のチェックポイントを設定し，このチェッ クポイントと CSG で定義された工作物との内外判別により干 涉検出を行う方法 ${ }^{11}$, 工具系の形状を $X Y$ 平面に投影しこの投 影した形状を包絡する矩形領域内に存在する工作物上の離散的 な点列データと工具系を包含する円すいとの内外判別により干 渉検出を行ら方法 ${ }^{2}$, 切削面の点群データをチェックポイント とし, 工具系の投影面の選択执よび投影面の領域分割の後, 工 具系の投影が存在する領域内のチェックポイントのみを工具座 標系に変換し, 工具座標系に扣いてチェックポイントと工具系 形状との内外判別により干渉検出を行い，干渉点の座標値扎よ び法線べクトルょり回避方向と回避角度を決定する方法 ${ }^{3)}$, 工 具干涉検出処理の後, その位置で取り得るすべての工具姿勢と それらの姿勢に対する干渉の有無の関係を表すC-Space を用 いて工具干渉回避を行う方法 ${ }^{4)}$ 等である.

しかしながら, 今までの研究は, 工具系もしくはテーブル系 の干渉検出の対象物を限定したものであること, 工具系, テー

* 原稿受付 平成 9 年 2 月 5 日

** 正会員 (財)機械振興協会技術研究所（東久留米市八幡町 1-1 12)

*** 正 会 員 法政大学工学部 (小金井市梶野町 3-7-2)

†正 会 員 大阪大学工学部（現, 国立高知工業高等専門学校；南国 市物部乙 200 番 1)
ブル系の一方を離散的な点列データとして干渉検出を行ってい ることにより，干渉検出漏れ等の問題点を有する．すなわち， 同時 5 軸制御加工.用 CAM ソフトウェアにおける工具干渉検出 と回避機能には，工具系とテーブル系間の総合的な干渉検出括 よび回避機能が必要である.

そこで本研究では，半球，円すいおよび円柱のプリミティブ で構成される工具系と許容誤差内で三角形のポリゴンパッチで 近似されたテーブル系間に生じる干渉を漏れなく確実に検出を 行ら方法扣よびポリゴンパッチに対する干渉回避方法を提案す る.さらに，この手法を組み込んだ同時 5 軸制御加工用 CAM ソフトウェアにより工具経路を自動生成し，その工具経路に基 ついて，加工実験を行うことによりその有効性および実用性を 検証する。

\section{2. 工具干渉の検出}

本研究では，工具，工具ホルダ，スピンドルおよび主軸頭を 工具系，工作物，ジグ扣よびテーブルをテーブル系，工具系と テーブル系間に生じる干渉を工具干渉と定義し，この工具干渉 の検出と回避を研究対象としている. 取り扱う工具はボールェ ンドミルのみではなく, ェンドミル，テーパボールェンドミ ル，テーパェンドミル，ブルノーズ，ブルノーズューンも対象 とする．ただし，ボールェンドミル，テーパボールェンドミル 以外の工具に関しては，工具軸ベクトルは常に切削点に拈ける 法線ベクトル，送り方向を表す接線ベクトルと同一平面に存在 するものとする．図 1 に干渉検出の対象である工具系，図 2 に テーブル系の例を示す.

ここで，工具干渉の検出にあたっては，テーブル系の各面は 工具径より短い稜線を 1 本含さ三角形のポリゴンパッチ（以 下，単にポリゴンパッチと記す）で，工具系はプリミティブで 定義されているものとする．このことにより，工具干渉検出問 題は, 工具系のプリミティブとテーブル系のポリゴンパッチの 棱線との交差検出問題に置換できる.

具体的な処理においては，まず，ラフチェックにより干渉の 可能性のあるポリゴンパッチを選択する。ついで, 図 3 に示す ように，工具中心を原点 $\mathbf{O}_{t}$, 工具軸ベクトルを $Z_{t}$ 軸, $Z_{t}$ 軸 と送り方向を表す接線ベクトル $\boldsymbol{F}$ の外積を $\boldsymbol{Y}_{t}$ 軸とする直交 


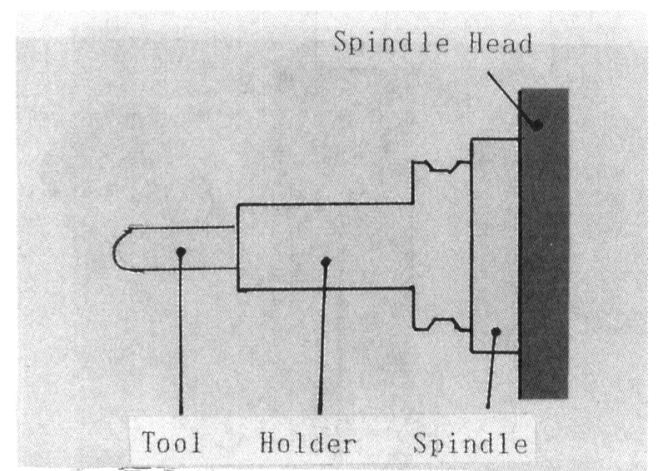

Fig. 1 Tool system

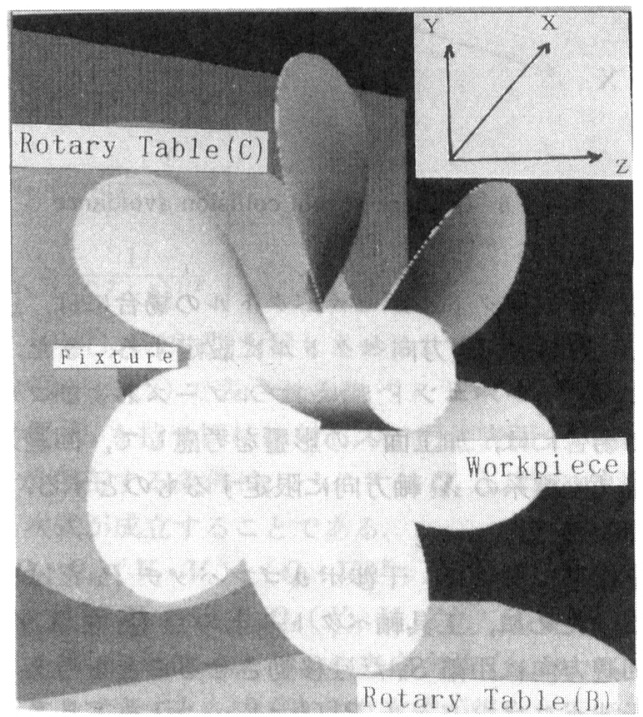

Fig. 2 Table system

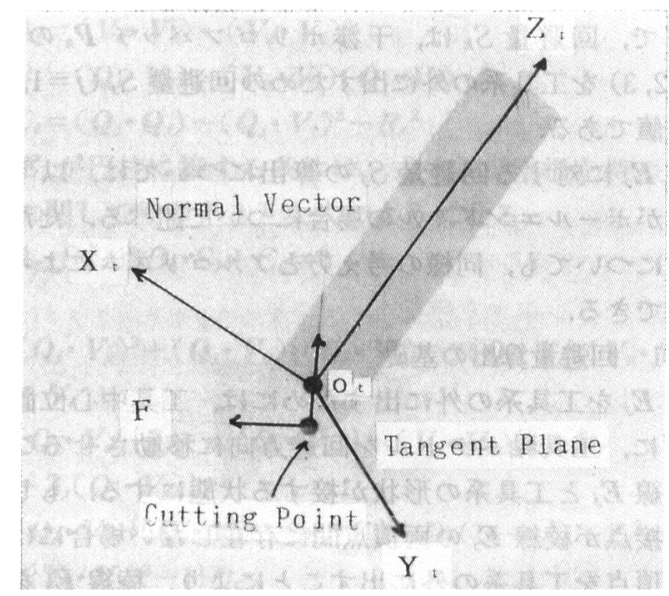

Fig. 3 Definition of tool coordinate system

座標系（以下，工具座標系と記す）を設定する。この直交座標 系に招いて, 選択されたポリゴンパッチに対してのみ, 工具系 のプリミティブとの交差判別を行うことにより工具干渉の検出 を行う.

開発したシステムは, 以下のよらな手順で翼面（自由曲面） をポリゴンパッチの集合体で近似する.

翼最大径, 翼最小径, レーキ曲線の曲率およびピックフィー ド量に基づき, 翼面に対する切断面（円筒面）の位置（円筒半 径）と個数を決定する. 次に, 翼面と各切断面との交点群を収 束計算により求める. この後に, 相隣り合ら切断面上の交点群
を頂点とする三角帯を決定し，この三角帯により翼面を近似す る.な括, 上述の翼面と切断面との交点群の計算に扣いては, 交点間の弦偏差が指定されたトレランス（0.05〜0.002 mmの 範用で指定可能）内になるように考慮している.

\section{1 ラフチェックによる可能ポリゴンパッチの選択}

工具干渉を確実に, かつ短時間で検出するため, 前処理とし て以下のようなラフチェックを行う。

工具系の形状，指定された工具中心位置执よび工具軸ベクト ルに基づいて（図 3), 工具系を包含する円すいを定義する. この円すいを $X Y$ 平面に投影し，この投影後の形状とテーブ ル系の各ポリゴンパッチの稜線との交差判別を行う．その結 果, 少なくても頂点の 1 点が内部に存在する場合，あるいは両 頂点間で稜線と交差する場合を検出し, 検出された稜線を含も ポリゴンパッチをチェックポリゴンパッチとして選択する.

\section{2 座標変換}

工具系のプリミティブとテーブル系のチェックポリゴンパッ チとの交差判別を行らには, ワーク座標系で定義されている テーブル系のチェックポリゴンパッチを工具座標系に変換する 必要がある。い屯, 工具座標系の $\boldsymbol{X}_{t}$ 軸, $\boldsymbol{Y}_{t}$ 軸, $\boldsymbol{Z}_{t}$ 軸の単位 ベクトルの方向余弦扰よび原点 $\mathbf{O}_{t}$ の座標をそれぞれ $\left(\lambda_{1}, \mu_{1}\right.$, $\left.\nu_{1}\right),\left(\lambda_{2}, \mu_{2}, \nu_{2}\right),\left(\lambda_{3}, \mu_{3}, \nu_{3}\right),\left(X_{0}, Y_{0}, Z_{0}\right)$ とすれば, 空間の 任意の一点 $\mathbf{P}$ の具座標系に関する座標 $\left(X_{t}, Y_{t}, Z_{t}\right)$ は, ワーク座標系に関する座標 $\left(X_{w}, Y_{w}, Z_{w}\right)$ と原点 $\mathbf{O}_{t}$ の座標抒 よび工具座標系の各軸の方向余弦で表される

この関係をマトリクスを用いて表現すれば次式となる.

$\left[\begin{array}{llll}X_{t} & Y_{t} & Z_{t} & 1\end{array}\right]=\left[\begin{array}{llll}X_{w} & Y_{w} & Z_{w} & 1\end{array}\right] \cdot T^{-1}$

$$
T=\left[\begin{array}{llll}
\lambda_{1} & \mu_{1} & \nu_{1} & 0 \\
\lambda_{2} & \mu_{2} & \nu_{2} & 0 \\
\lambda_{3} & \mu_{3} & \nu_{3} & 0 \\
X_{0} & Y_{0} & Z_{0} & 1
\end{array}\right]
$$

ここで, $T$ は工具座標系からワーク座標系への変換マトリク ス， $T^{-1}$ は $T$ の逆マトリクスである.

したがって，指定された切削点，切削点での工具軸ベクトル 扣よび送り方向を表す接線べクトルに基づき, 工具座標系の $\boldsymbol{X}_{t}$ 軸, $\boldsymbol{Y}_{t}$ 軸, $\boldsymbol{Z}_{t}$ 軸の各単位べクトルの方向余弦をそれぞれ 算出し, ワーク座標系のチェックポリゴンパッチの各頂点と法 線ベクトルを式 (1) により工具座標系に変換する.

2.3 プリミティブとポリゴンパッチの干渉検出

工具系のプリミティブとテーブル系の稜線 $\boldsymbol{E}_{j}(j=1,2,3)$ で 定義される三角形のチェックポリゴンパッチとの干渉検出の手 順を以下に示す.

2.3.1 球とポリゴンパッチの干渉検出

原点を中心とする球とポリゴンパッチとの干渉は次の順序で 検出できる. (1) 頂点 $\boldsymbol{Q}_{i}(i=1,2,3)$ のちち少なくとも1点が 球の内部に存在する場合は干渉する.（2）原点とポリゴンパッ チ間の距離が球の半径より大きい場合は干渉しない.（3）球と ポリゴンパッチの交差円が 3 頂点で定義される三角形に包含さ れる場合は干渉寸る. (4) 稜線 $\boldsymbol{E}_{j}(j=1,2,3)$ のらち少なくと も 1 本が球と交差し, かつその交点が稜線の頂点間に存在する 場合は干渉する.

2.3.2 円柱とポリゴンパッチの干渉検出

点 $\boldsymbol{Q}_{b}\left(0,0, Z_{b}\right)$ を工具先端側底面の中心, $\boldsymbol{Z}_{t}$ 軸を中心軸と すると, 円柱とポリゴンパッチとの干渉は次の順序で検出でさ る. (1) 頂点 $\boldsymbol{Q}_{i}(i=1,2,3)$ の $Z$ 座標值の最大值が $Z_{b}$ より小 さい場合は干渉しない. (2) 頂点 $\boldsymbol{Q}_{i}(i=1,2,3)$ と $\boldsymbol{Z}_{t}$ 軸間の 


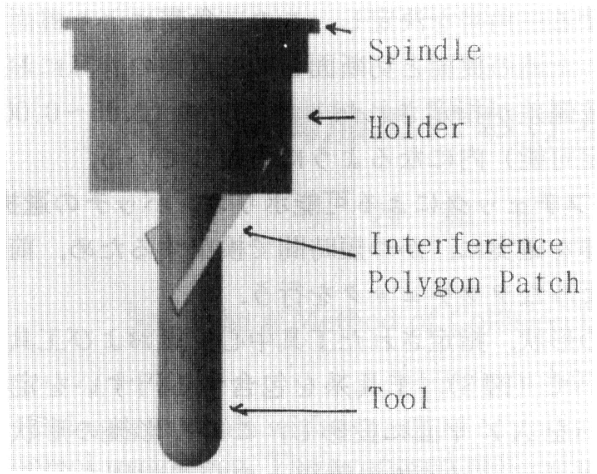

Fig. 4 Example of collision check between a polygon patch and the tool system

距離が円柱の半径より小さい場合は干渉する.（3）棱線 $\boldsymbol{E}_{j}$ $(j=1,2,3)$ のちち少なくとも 1 本が円柱と交差し, からその 交点が稜線の頂点間に存在する場合は干渉する.

2.3.3 円すいとポリゴンパッチの干渉検出

点 $\boldsymbol{Q}_{t}\left(0,0, Z_{t}\right)$ を主軸側底面の中心, 点 $\boldsymbol{Q}_{b}\left(0,0, Z_{b}\right)$ を工 具先端側底面の中心, 点 $\boldsymbol{Q}_{v}\left(0,0, Z_{v}\right)$ 老頂点, $\boldsymbol{Z}_{t}$ 軸を中心 軸, $\theta$ を半頂角とすると, 円すいとポリゴンパッチとの干渉は 次の順序で検出できる.（1）稜線の頂点 $\boldsymbol{Q}_{i}(i=1,2,3)$ の $Z$ 座 標值の最大值が $Z_{b}$ より小さいか, あるいは最小値が $Z_{t}$ より 大きい場合は干渉しない.（2）頂点 $\boldsymbol{Q}_{i}(i=1,2,3)$ と $\boldsymbol{Z}_{t}$ 軸間 の距離が頂点 $\boldsymbol{Q}_{i}$ の $Z$ 值に対応する円すい半径より小さい場合 は干渉する.（3）稜線 $\boldsymbol{E}_{j}(j=1,2,3)$ のらち少なくとも 1 本が 円すいと交差し，かつその交点が稜線の頂点間に存在する場合 は干渉する。

\section{4 工具干渉検出の手順}

工具系とテーブル系間に生じる総合的な工具干渉の検出は, テーブル系のすべてのチェックポリゴンパッチに対し，工具先 端, 工具, 工具ホルダ，スピンドル执よび主軸頭等の形状の順 に前節の手順により行う。干渉が検出された場合は，このポリ ゴンパッチ（以下，干渉ポリゴンパッチと記す）に対して干渉 を回避でさる工具軸べクトルを算出し，工具姿勢を変更する. もし，干渉が検出されなければ，初めに指定された工具軸べク トルが指定された切削点に抢ける干渉のない工具軸ベクトルと なる．図 4 は工具ホルダと工具に干渉した単一ポリゴンパッチ の検出例である.

\section{3. 干渉回避の方法}

干渉回避は, 工具先端の切削点あるいはオフセット位置を変 化させずに，工具軸ベクトルを回避方向に移動させることによ り，すべての干渉ポリゴンパッチを前章で定義した工具系の範 用外に出すことにより行う.

ここで，切削点あるいはオフセット位置は工具形状により異 なり，ボールエンドミルとテーパボールエンドミルの場合は工 具中心位置, エンドミルとテーパェンドミルの場合は切削点, ブルノーズとブルノーズコーンの場合はノーズ中心位置であ る.

\section{1 回避方向}

工具がボールェンドミルとテーパボールェンドミルの場合に は，各干渉ポリゴンパッチの法線ベクトルを工具座標系の $X_{t} Y_{t}$ 面上に投影し単位化したベクトルの合成べクトルを回避 方向ベクトルとする方法が提案されている3). ここでは, この 考え方を踏襲する。

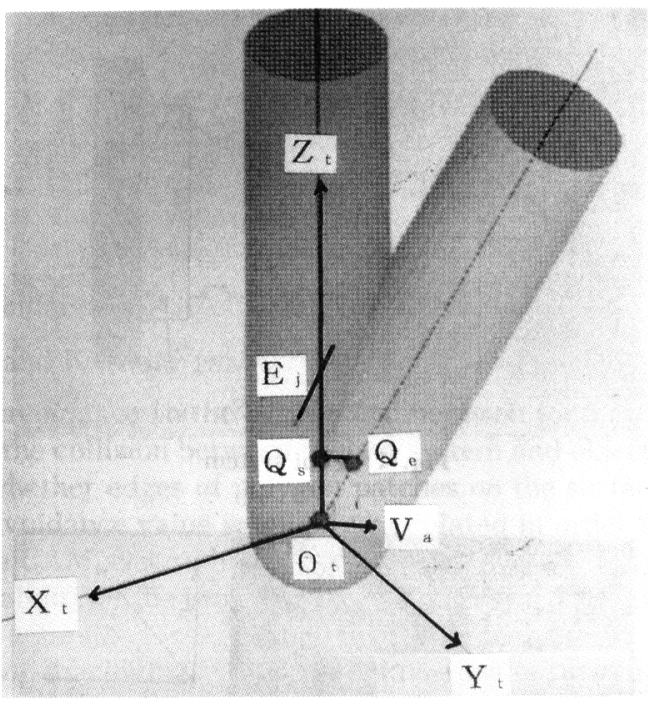

Fig. 5 Concept of tool collision avoidance

ただし，合成ベクトルがゼロベクトルの場合には，工具座標 系の $\boldsymbol{X}_{t}$ 軸方向を回避方向ベクトルに設定する。 また，工具が エンドミル，テーパエンドミル，ブルノーズ拈よ゙ブルノーズ コーンの場合には, 加工面への影響を考慮して, 回避方向べク トルは工具座標系の $\boldsymbol{X}_{\mathrm{t}}$ 軸方向に限定するものとする.

\section{2 回避 量}

工具座標系に拈いて，干渉ポリゴンパッチ $\boldsymbol{P}_{k}$ だけを工具系 の外に出すために，工具軸ベクトル上の点 $\boldsymbol{Q}_{s}$ を $X_{t} Y_{t}$ 平面と 平行に回避方向に距離 $S_{k}$ だけ移動させることを考学ると，す ベての干渉ポリゴンパッチ $\boldsymbol{P}_{k}(k=1, \cdots, n)$ を工具系の外に出 すために必要な回避量 $S$ はすべての $S_{k}(k=1, \cdots, n)$ 中の最大 值となる。

ここで, 回避量 $S_{k}$ は, 干渉ポリゴンパッチ $\boldsymbol{P}_{k}$ の稜線 $\boldsymbol{E}_{j}$ $(j=1,2,3)$ を工具系の外に出すための回避量 $S_{j}(j=1,2,3)$ 中 の最大值である。

稜線 $\boldsymbol{E}_{j}$ に対する回避量 $S_{j}$ の算出については, 以下に，使 用工具がボールェンドミルの場合について述べる。ただし，他 の形状についても，同様の考方とアルゴリズムによって行う ことができる。

\section{2 .1 回避量算出の基礎}

稜線 $\boldsymbol{E}_{j}$ を工具系の外に出すためには，工具中心位置を変化 させずに，工具軸ベクトルを回避方向に移動させることによ り，稜線 $\boldsymbol{E}_{j}$ と工具系の形状が接する状態にする. もし，この 状態で接点が稜線 $\boldsymbol{E}_{j}$ の両頂点間に存在しない場合には，接点 に近い頂点を工具系の外に出すことにより，稜線 $\boldsymbol{E}_{j}$ を工具系 の外に出すことができる。また，接点が両頂点間に存在する場 合には，このときの移動量が算出すべき回避量となる.

図 5 に示すよらに，稜線 $\boldsymbol{E}_{j}$ を工具系の外に出すために，工 具軸ベクトル上の点 $\boldsymbol{Q}_{s}$ を $X_{t} Y_{t}$ 平面と平行する回避方向べク トル $\boldsymbol{V}_{a}$ の方向に回避量 $S_{j}$ だけ移動させる。この状態に扣い $\tau$, 原点 $\boldsymbol{O}_{t}$ から点 $\boldsymbol{Q}_{s}$ の移動後の点 $\boldsymbol{Q}_{e}$ に至るべクトルの単 位べクトル $V_{t}$ が回避後の工具軸べクトルとなる。ここで，回 避方向べクトル $\boldsymbol{V}_{a}$ の方向余弦を $\left(l_{a}, m_{a}, 0\right)$, 点 $\boldsymbol{Q}_{s}$ の夾標を $(0,0,1)$ とすると, 工具軸ベクトル $V_{t}$ の方向余弦 $\left(l_{t}, m_{t}, n_{t}\right)$ は, 次式に示すように, 回避方向ベクトル $\boldsymbol{V}_{a}$ の方向余弦と回 避量 $S_{j}$ を用いて表すことができる。 


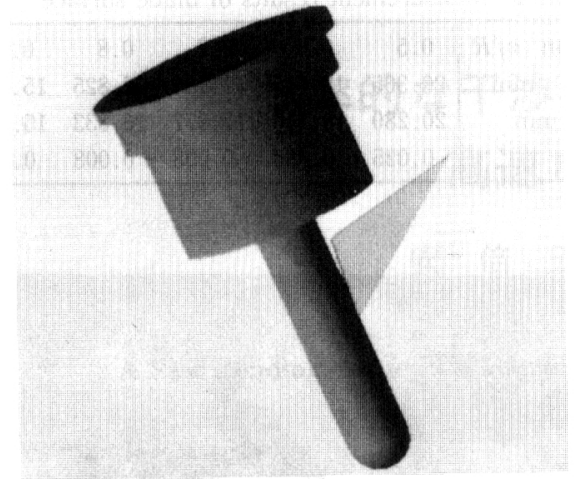

Fig. 6 Example of tool collision avoidance

$$
\left.\begin{array}{l}
l_{t}=\frac{l_{a} \cdot S_{j}}{\left(S_{j}{ }^{2}+1\right)^{1 / 2}} \\
m_{t}=\frac{m_{a} \cdot S_{j}}{\left(S_{j}{ }^{2}+1\right)^{1 / 2}} \\
n_{t}=\frac{1}{\left(S_{j}{ }^{2}+1\right)^{1 / 2}}
\end{array}\right\}
$$

\section{2 .2 円柱に稜線 $\boldsymbol{E}_{j}$ を接しさせるための回避量}

方向余弦が式 (2) で表される軸べクトル $\boldsymbol{V}_{t}$, 軸上の点 $\boldsymbol{O}_{t}$ および半径 $R_{t}$ を持つ円柱に対して, 円柱表面上に稜線 $\boldsymbol{E}_{j}$ 上 の点 $\boldsymbol{Q}_{t}$ が存在する条件は, ベクトル $\boldsymbol{Q}_{t}$ と $\boldsymbol{V}_{t}$ の外積の大き さより，次式が成立することである。

$$
\left(\boldsymbol{Q}_{t} \cdot \boldsymbol{Q}_{t}\right)\left(\boldsymbol{V}_{t} \cdot \boldsymbol{V}_{t}\right)-\left(\boldsymbol{Q}_{t} \cdot \boldsymbol{V}_{t}\right)^{2}=R_{t}{ }^{2}
$$

点 $\boldsymbol{Q}_{t}$ 老稜線 $\boldsymbol{E}_{j}$ の頂点 $\boldsymbol{Q}_{j}\left(X_{j}, Y_{j}, Z_{j}\right), \boldsymbol{Q}_{j}$ から $\boldsymbol{Q}_{j+1}$ に至 るべクトル $V_{e}$ の単位ベクトルの方向余弦 $\left(l_{e}, m_{e}, n_{e}\right)$ 执よび パラメータ $t$ で表すと, 式 (3) より次式が得られる.

$$
A_{t} \cdot t^{2}+2 B_{t} \cdot t+C_{t}=0
$$
ただし，

$$
\begin{aligned}
& A_{t}=\left(\boldsymbol{V}_{e} \cdot \boldsymbol{V}_{e}\right)-\left(\boldsymbol{V}_{e} \cdot \boldsymbol{V}_{t}\right)^{2} \\
& B_{t}=\left(\boldsymbol{Q}_{j} \cdot \boldsymbol{V}_{e}\right)-\left(\boldsymbol{V}_{e} \cdot \boldsymbol{V}_{t}\right)\left(\boldsymbol{Q}_{j} \cdot \boldsymbol{V}_{t}\right) \\
& C_{t}=\left(\boldsymbol{Q}_{j} \cdot \boldsymbol{Q}_{j}\right)-\left(\boldsymbol{Q}_{j} \cdot \boldsymbol{V}_{t}\right)^{2}-R_{t}{ }^{2}
\end{aligned}
$$

棱線 $\boldsymbol{E}_{j}$ が円柱に接する条件は, 式 (4) が重根を持つことか ら, $S_{j}$ に関して整理すると次式のようになる.

$$
A_{s} \cdot S_{j}{ }^{2}+2 B_{s} \cdot S_{j}+C_{s}=0
$$

ただし，

$$
\begin{aligned}
A_{s}= & \left(\boldsymbol{Q}_{j} \cdot V_{e}\right)^{2}+\left(\boldsymbol{Q}_{j} \cdot V_{a}\right)\left\{\left(\boldsymbol{Q}_{j} \cdot V_{a}\right)-2\left(\boldsymbol{Q}_{j} \cdot V_{e}\right)\left(\boldsymbol{V}_{e} \cdot V_{a}\right)\right\} \\
& +V_{s} \\
B_{s}= & \left(\boldsymbol{Q}_{j} \cdot V_{a}\right)\left\{Z_{j}-n_{e}\left(\boldsymbol{Q}_{j} \cdot V_{e}\right)\right\}+\left(\boldsymbol{V}_{e} \cdot \boldsymbol{V}_{a}\right)\left\{n_{e} \cdot D_{r}\right. \\
& \left.-Z_{j}\left(\boldsymbol{Q}_{j} \cdot V_{e}\right)\right\} \\
C_{s}= & \left(\boldsymbol{Q}_{j} \cdot V_{e}\right)\left\{\left(\boldsymbol{Q}_{j} \cdot V_{e}\right)-2 n_{e} \cdot Z_{j}\right\}-D_{r}\left(1-n_{e}{ }^{2}\right)+Z_{j}{ }^{2} \\
V_{s}= & \left\{\left(\boldsymbol{V}_{e} \cdot V_{a}\right)^{2}-1\right\} D_{r} \\
D_{r}= & \left(\boldsymbol{Q}_{j} \cdot \boldsymbol{Q}_{j}\right)-R_{t}{ }^{2}
\end{aligned}
$$

回避量の具体的な算出には，まず，式 (5)の正の実根で，か つ最大の根 $S_{j}$ に対して, 式 (2)より, 工具軸ベクトルの方向 余弦を求める。つついて, 式 (4)を解き, 接点を与克るパラ メータ $t$ を算出する. この $t$ の值が正で, かつ頂点 $\boldsymbol{Q}_{j}, \boldsymbol{Q}_{j+1}$ 間の距離より小さい場合には， $S_{j}$ が稜線 $\boldsymbol{E}_{j}$ に対する回避量と なる. 図 4 に示した干渉状態に対して回避させた例を図 6 に示 寸.

\section{2 .3 円柱と頂点 $\boldsymbol{Q}_{j}$ に対する回避量}

方向余弦が式 (2) で表される軸べクトル $\boldsymbol{V}_{t}$, 軸上の点 $\mathbf{O}_{t}$ 扎よび半径 $R_{t}$ を持つ円柱に対して, 頂点 $\boldsymbol{Q}_{j}\left(X_{j}, Y_{j}, Z_{j}\right)$ が円 柱表面上に存在する条件は, ベクトル $\boldsymbol{Q}_{j}$ と $V_{t}$ の外積の大き

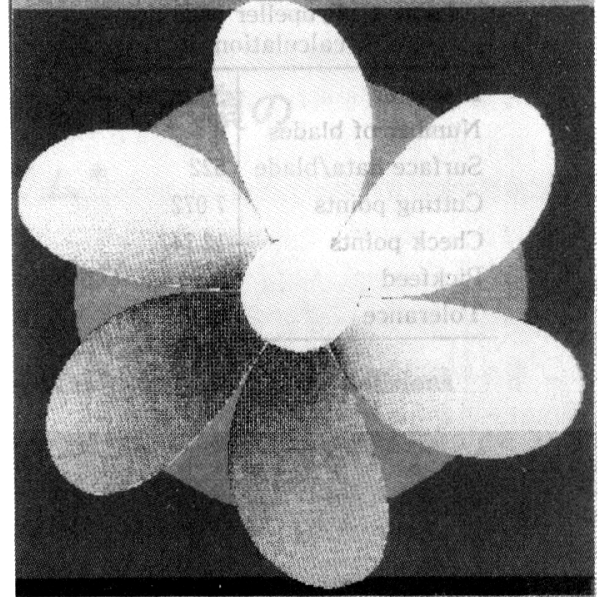

Fig. 7 Propeller used in machining

さより， $\boldsymbol{Q}_{j}$ と $\boldsymbol{V}_{t}$ に対して, 式 (3) と同様の関係が成立する ことである. この式を $S_{j}$ について整理すると, 次式が得られ る.

$$
\left\{D_{r}-\left(\boldsymbol{Q}_{j} \cdot \boldsymbol{V}_{a}\right)^{2}\right\} S_{j}{ }^{2}-2 Z_{j}\left(\boldsymbol{Q}_{j} \cdot \boldsymbol{V}_{a}\right) S_{j}+D_{r}-Z_{j}^{2}=0
$$

ただし， $D_{\mathrm{r}}=\left(\boldsymbol{Q}_{j} \cdot \boldsymbol{Q}_{j}\right)-R_{t}{ }^{2}$.

式 (6) の正の実根で, かつ最大の根が頂点 $\boldsymbol{Q}_{j}$ に対寸る回避 量 $S_{j}$ となる.

\section{3 座標系の逆変換}

前節で得られる回避量 $s$ 基づいて, 工具座標系に打ける干 渉回避後の工具軸べクトルの力向余弦を式 (2) で求めた後に, 2.2 節で述べた工具座標系からワーク座標系への変換マトリク スにより,ワーク座標系における干渉回避後の新工具軸べクト ルを決定する. 以上の処理により，すべての干渉ポリゴンパッ チを工具系の外に出すことができる. しかしながら, この回避 処理によって, 新たに他のポリゴンパッチとの干渉を発生させ ることもある. したがって, 新工具軸べクトルによって工具系 とテーブル系との干渉検出を再度行い, 干渉が検出されなくな るまで, 以上の過程を繰り返す. 繰返しの際, 干渉回避が制限 回数を越えた場合は干渉回避不能, 回避量が制限值を越えた場 合は連続切削不能状態として検出している.

な拉, 繰返しの過程に打いて, ベクトル $\boldsymbol{V}_{t}^{(0)}, \boldsymbol{V}_{t}^{(i-1)}$ 执よ び $\boldsymbol{V}_{t}^{(i)}$ が同一平面に存在し, かつ $s^{(i)}<s^{(i-1)}$ の場合には, 回 避方向ベクトルを送り方向を表す接線べクトル $\boldsymbol{F}$ の方向に設 定することとした.ここで， $\boldsymbol{V}_{t}^{(i)}, s^{(i)}$ は，それぞれ繰返しi 回目の工具軸ベクトルと回避量である.

\section{4. 加 工 実 験}

加工対象物として，図７に示す水槽実験用模型プロペラを取 り上げ，考案した干渉検出手法および干渉回避手法を組み込ん だ同時 5 軸制御加工用 CAM ソフトウェアにより, 工具経路を 生成し加工実験を行った．表 1 に加工実験に用いたプロペラの 仕様を, 図 8 にプロペラの翼面加工に対して生成した工具経路 の例を示す。加工実験に用いた被削材はアルミニウム (A $5052 \mathrm{~S})$, 使用工具は $\phi 16 \mathrm{~mm}$ のボールェンドミル, 工具 突出し長さは $110 \mathrm{~mm}$ である. 翼面仕上加工時の主軸回転数, 送り速度拈よびピックフィード量は, それぞれ $1800 \mathrm{rpm}$, $600 \mathrm{~mm} / \mathrm{min}, 1.0 \mathrm{~mm}$ である.

また，加工実験での荒加工から仕上加工までの工程は，次の 通りである。

円盤状の被削材に対して 3 軸制御加工により, 仕上代 0.7 
Table 1 Propeller used in calculation

\begin{tabular}{l|l}
\hline Diameter & $300 \mathrm{~mm}$ \\
Number of blades & 6 \\
Surface data/blade & 522 \\
Cutting points & 7072 \\
Check points & 12747 \\
Pickfeed & $2.0 \mathrm{~mm}$ \\
Tolerance & $0.005 \mathrm{~mm}$ \\
\hline
\end{tabular}

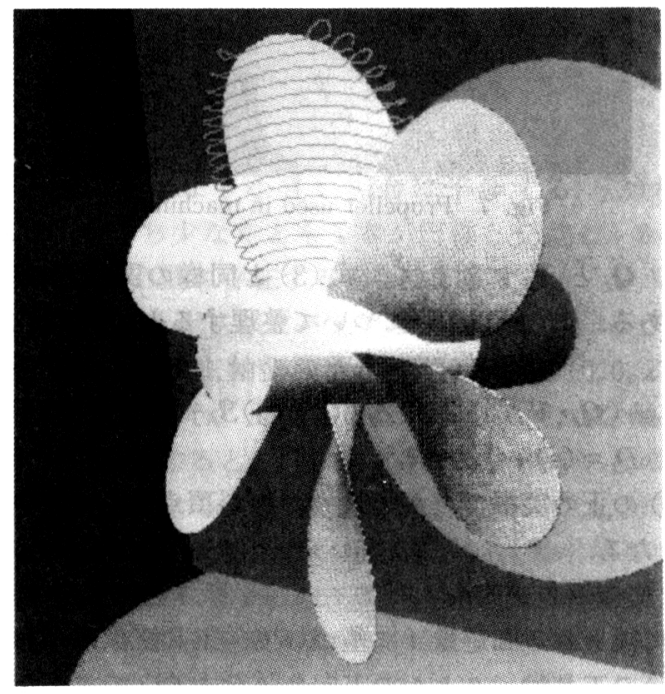

Fig. 8 Generated CL-data

$\mathrm{mm}$ で翼輪郭間の余肉部を除去し，オーバハングの存在しない 翼面部分は，仕上代 $3.0 \mathrm{~mm}$ で荒加工を実施した。 その後，5 軸制御加工によりピックフィード量 $2.0 \mathrm{~mm}$, 仕上代 $0.7 \mathrm{~mm}$ で中荒加工，ピックフィード量 $1.5 \mathrm{~mm}$, 仕上代 $0.3 \mathrm{~mm}$ で中 仕上加工，ピックフィード量 $1.0 \mathrm{~mm}$ の仕上加工を行った．各 工程ごとに, 仕上面に対して仕上代だけ工具半径をオフセット して干渉チェックを行いCL データを算出した。 なお，工具経 路の生成に使用した計算機は IBM RISC system 6000/560，工 作機械は新日本工機社製 FSP-50 H である。

図 7 に示したプロペラの翼面と翼面間の狭部の加工に拈いて は，干渉を回避するために同時 5 軸制御加工が必要であり，特 に，翼面加工を段取換觉を省いた加工で行らためには，工具系 とテーブル系間の総合的な干渉検出と干渉回避処理が不可欠で ある. 表 1 に示した仕様のプロペラをチェックポイントのみで 干渉検出を行った場合の検出回数は 156 回, 棱線で干渉検出を 行った場合の検出回数は 165 回であった。このことから確実に 干渉検出を行うには, ポリゴンパッチの稜線で干渉検出を行う 手法が有効であることが分かる，次に，実加工後のプロペラ翼 面 (圧力面) の母線位置での測定結果（三井造船昭島研究所の ご協力による）を表 2 に示す。この測定結果により，水槽実験 用模型プロペラの要求精度 $\pm 0.05 \mathrm{~mm}$ を満足する結果を得た ことが分かる. あた, 実加工後の水槽実験用模型プロペラの形 状を図 9 に示す.
Table 2 Measurement results of blade surface

\begin{tabular}{l|rrrrrr}
\hline Measuring position $r / R$ & \multicolumn{1}{c}{0.5} & \multicolumn{1}{c}{0.6} & \multicolumn{1}{c}{9.7} & \multicolumn{1}{c}{0.8} & \multicolumn{1}{c}{0.9} & 0.95 \\
Theoretical value $\mathrm{mm}$ & 20.305 & 19.145 & 17.985 & 16.825 & 15.665 & 15.085 \\
Measured value $\mathrm{mm}$ & 20.280 & 19.110 & 17.977 & 16.833 & 15.655 & 15.069 \\
Error mm & 0.025 & 0.035 & 0.008 & -0.008 & 0.010 & 0.016 \\
\hline
\end{tabular}

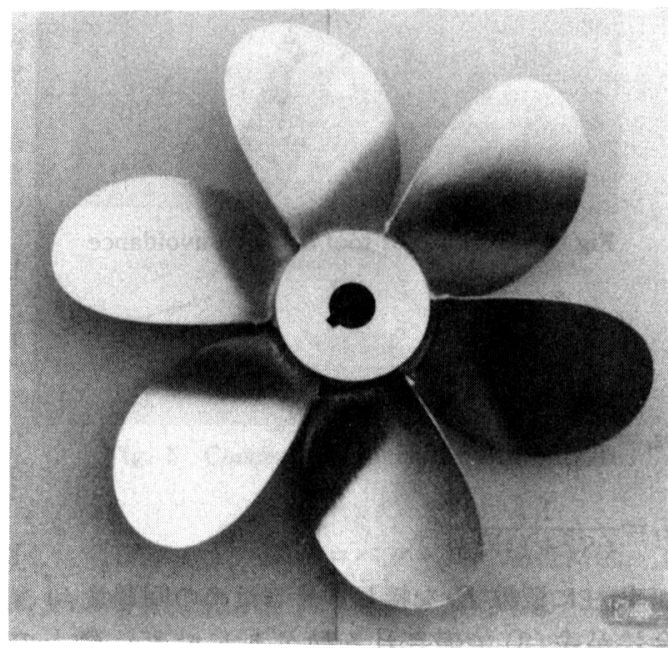

Fig. 9 Machined propeller

5. 結 論

本研究では，工具系とテーブル系間に生じる工具干渉に対し て，処理速度が早く，かつ信頼性の高い干涉検出手法扣よびポ リゴンパッチに対する干渉回避手法を考案し，この手法を水槽 実験用模型プロペラの実加工に適用して以下の結論を得た.

(1) 工具系とテーブル系の各ポリゴンパッチの稜線との交 差判別を基本とした検出漏れのない干渉検出方法を提案 し，その有効性を確認した。

（2）ベクトル外積，内積に基づく干渉ポリゴンパッチに対 する回避量の算出方法を示し，1回の回避処理ですべての 干渉ポリゴンパッチを回避する方法を提案した.

（3）加工実験を行い，工具干渉のない工具経路を自動的に 生成できることを確認した。

（4）実作業分野に応用することにより，開発した同時 5 軸 制御加工用 CAM ソフトゥェアの有効性を確認した。

\section{参 考 文 献}

1）竹内芳美, 清水弘幸, 出村 健, 渡辺隆弘, 伊藤哲也：ソリッドモ デルに基づく 5 軸制御加工，精密工学会誌，56,11（1990）2063.

2）鈴木 裕, 桑野義正, 後藤勝征, 竹内芳美, 佐藤 眞: 5 軸加工用 CAM システムの開発, 精密工学会誌, 60, 6 (1994) 832 .

3）趙䀘明，葛東方，堤 正臣：同時 5 軸制御マシニンダセンタ用 CAM システムに関する研究，精密工学会誌，61，12（1995） 1745.

4）森重功一，加瀬 究，竹内劳美：2次元 Configuration 空間を用い た 5 軸制御加工に打ける工具干涉回避法, 精密工学会誌, 62,1 (1996) 80.

5）矢野憲太郎：代数学と幾何学，裳華房，(1968) 